TAPROBANICA, ISSN 1800-427X. November, 2020. Vol. 09, No. 02: pp. 244-247.

(C) Research Center for Climate Change and Department of Biology, Faculty of Mathematics \& Natural Sciences, University of Indonesia, Depok 16424, INDONESIA.

http://www.taprobanica.org/

https://doi.org/10.47605/tapro.v9i2.242

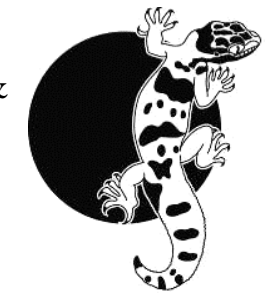

\section{The tallest canopy and the highest carbon stock for a forest stand in Sri Lanka}

The height of the canopy of a forest has been noted as an important structural parameter in characterizing particular forest types in Sri Lanka (Ashton et al. 1997, Koelmeyer 1957, Peeris 1975). However, only limited studies have been carried out on the carbon stocks of different natural forest types, which is also an important structural parameter of forests. As per the scientific literature mentioned above, the tallest canopy forests are wet zone lowland rain forests in the south western part of the country. The forests are dominated by trees of the family Dipterocarpaceae and reach a maximum canopy height of $45 \mathrm{~m}$ (Gunatilleke et al. 2008).

A preliminary botanical survey conducted in the hitherto unexplored Udakeeruwa forest in the eastern intermediate zone climatic zone, in Badulla district, revealed an unusually tall canopy of a natural forest patch dominated by dipterocarp trees. With the guidance of the local community, it was possible to record the height of a newly fallen mature tree of Dipterocarpus zeylanicus. The total height from the base of the stem to its apex green point was recorded as $72.3 \mathrm{~m}$. However, there could have been an error of $1-2 \%$ since the natural green apex point was difficult to recognise in the fallen tree. Moreover, some slender woody branches of the top part of the tree were broken away. This observation prompted a further study into the forest canopy height levels, and forest carbon content, which is often higher in taller forests.

There were two objectives for this study: (1) to understand the natural forest vertical structure with particular reference to canopy height, and (2) to investigate total carbon content of the tree flora. The studied forest area is located adjacent to Udakeeruwa Village (7.050902 N, 81.233480 E; alt. $513 \mathrm{~m}$ a.s.l.), in Badulla District, Sri Lanka. The area falls within the eastern intermediate climatic zone with mean annual rainfall from 2,000-2,500 $\mathrm{mm}$ (Survey
Department 1988). It was observed that the dipterocarp-dominated tall canopy forest patch under investigation is not widespread locally but confined to a small geographic area of approximately $2 \mathrm{~km}^{2}$, in a valley bottom surrounded by low hills (Fig. 1A).

Study of forest vertical structure and canopy height: Vertical structure of the forest was studied by drawing a forest profile diagram. A transect of size $100 \mathrm{~m} \times 5 \mathrm{~m}$, which was representative of the least disturbed area of mature forest was selected. A profile diagram was drawn to show the overall vertical appearance of the forest. Scaled line drawings of all trees above or equal to $50 \mathrm{~cm}$ girth at breast height were made. Trees of higher girth classes were measured to better highlight taller trees in the profile diagram. The height of each tree was measured using a Suunto hypsometer (Suunto Oy Company, Finland) which is based on simple trigonometric principles. The vertical forest profile (Fig. 2) drawn for the sample site shows that large diameter trees are vertically organized into three strata; canopy (55-67 m), sub canopy $(30-40 \mathrm{~m})$ and under story $(15-25 \mathrm{~m})$. It is interesting to note that none of the natural forest canopies elsewhere in Sri Lanka are reported to be $55-67 \mathrm{~m}$ high. This unusual height may be due to the following reasons: (a) the forest being situated in a valley flanked by two hills ensures it is well protected from strong winds and hence trees can grow to great heights with no natural obstructions; (b) the hills on both sides run north to south, which limits the period of direct sunlight reaching the valley floor (Fig. 1B). Therefore, it is likely that strong competition for light has promoted vertical growth; and apparently, the valley being a fertile area, can sustain high biomass forests.

The tallest tree recorded was a $67 \mathrm{~m}$ Shorea dyeri (Diperocarpaceae). This tree is $6.3 \mathrm{~m}$ shorter than the fallen Dipterocarpus zeylanicus measured previously in the same forest stand. However, even when used correctly, the Sunnto hypsometer can have an error of about $2.5 \%$ (Brack \& Wood 1998). So far, the tallest tropical 
tree in the world has been measured as $94.1 \mathrm{~m}$ using laser technology; a tree in Borneo, tentatively identified as Shorea species (Dockril 2016).

Assessment of forest carbon: Enumeration was done for woody plants (mainly trees and some lianas) having a girth at breast height of 10 $\mathrm{cm}$ or above (Table 1 ). Trees were enumerated in 20 plots, $10 \times 10 \mathrm{~m}$ in size. All the plants species enumerated were identified using field guides and referring specimens to the National Herbarium of Sri Lanka. Plots were laid randomly in areas judged to be representative of dipterocarp forest in the field. Girth values of plants were used in calculating species specific carbon content using the following allometric equations:

Above ground biomass in $\mathrm{kg}(\mathrm{AGB})=21.297-$ $6.953(\mathrm{DBH})+0.740(\mathrm{DBH})^{2}$ (Brown1997). $\mathrm{DBH}=$ diameter at breast height in centimetres.

Below Ground biomass in $\mathrm{kg}(\mathrm{BGB})=\mathrm{AGB}(\mathrm{kg})$ $\times 0.127$ (Brown \& Iverson 1992). Total biomass in $\mathrm{kg}=\mathrm{AGB}+\mathrm{BGB}$; total carbon content=total biomass $[\mathrm{kg}] \times 0.474($ Martin \& Thomas 2011).

The overall analysis of the girth data shows that the total carbon stock of the woody flora of a $2,000 \mathrm{~m}^{2}$ area is $140,816.85 \mathrm{~kg}(704.08$ $\mathrm{Mt} / \mathrm{ha}$ ). That amount of sequestered carbon is distributed among 53 woody plant species (Table 1) with 627 individuals. The five leading woody species in descending order of percentage carbon stock are Dipterocarpus zeylanicus (59.75\%), Shorea dyeri (22.74\%), Mallotus fuscescens (5.06\%), Artocarpus nobilis $(2.16 \%)$ and Bhesa ceylanica (1.68\%). The total forest carbon stock per ha in this forest is higher than that of comparable forest types in the wet zone of Sri Lanka, assessed by Chave et al. (2008). Once AGB data from Chave et al. (2008), is converted to total carbon content, it amounts to $403.35 \mathrm{Mt} / \mathrm{ha}$ for woody plants equal to or above the $1 \mathrm{~cm}$ diameter at breast height used in that study. The pattern of distribution of carbon content among species is highly asymmetric, with $82.49 \%$ of the total carbon stock in two species: Dipterocarpus zeylanicus and Shorea dyeri. Both species are massive trees of the Dipterocarpaceae family (Fig. 1C). Moreover, $91.39 \%$ of the total carbon stock is within the first five leading species. The balance of $8.51 \%$ carbon stock is spread over 49 other woody species.

Table 1. Estimated carbon content of different woody species

\begin{tabular}{clr}
\hline No & \multicolumn{1}{c}{ Plant species } & Carbon $(\mathrm{kg})$ \\
1 & Dipterocarpus zeylanicus & $84,140.72$ \\
2 & Shorea dyeri & $32,022.16$ \\
3 & Mallotus fuscescens & $7,120.89$ \\
4 & Artocarpus nobilis & $3,039.43$ \\
5 & Bhesa ceylanica & $2,369.72$ \\
6 & Mangifere zeylanica & $1,510.13$ \\
7 & Hydnocarpus venenata & $1,443.29$ \\
8 & Artocarpus heterophyllous & $1,162.45$ \\
9 & Ficus drupacea & 846.82 \\
10 & Myristica ceylanica & 803.25 \\
11 & Horsfieldia iryaghedhi & 796.32 \\
12 & Goniothalamus hookeri & 739.18 \\
13 & Garcinia quaesita & 671.77 \\
14 & Macaranga peltata & 567.25 \\
15 & Dimocarpus longan & 545.53 \\
16 & Agrostistachys indica & 444.73 \\
17 & Uvaria semecarpifolia & 429.17 \\
18 & Timonius flavescens & 321.46 \\
19 & Aporusa acuminata & 264.24 \\
20 & Calophyllum tomentosum & 251.17 \\
21 & Alstonia scholaris & 229.18 \\
22 & Litsea longifolia & 183.36 \\
23 & Antidesma sp. & 152.23 \\
24 & Entada pusaetha & 137.54 \\
25 & Dalbergia pseudo-sissoo & 110.07 \\
26 & Flacourtia indica & 86.80 \\
27 & Olax zeylanica & 81.86
\end{tabular}

\begin{tabular}{llr}
\hline No & \multicolumn{1}{c}{ Plant species } & Carbon $(\mathrm{kg})$ \\
28 & Stemonurus apicalis & 58.40 \\
29 & Rourea minor & 38.07 \\
30 & Syzygium aqueum & 29.38 \\
31 & Syzygium makul & 27.46 \\
32 & Areca catechu & 26.16 \\
33 & Strombosia ceylanica & 17.15 \\
34 & Eugenia rufo-fulva & 16.95 \\
35 & Palaquium hinmolpedda & 15.19 \\
36 & Acacia pennata & 12.92 \\
37 & Semecarpus nigro-viridis & 10.68 \\
38 & Caryota urens & 9.49 \\
39 & Cinnamomum verum & 9.49 \\
40 & Uncaria elliptica & 9.28 \\
41 & Euonymus walkeri & 9.28 \\
42 & Pandanus ceylanicus & 9.11 \\
43 & Nothopegia beddomei & 8.41 \\
44 & Connarus monocarpus & 6.84 \\
45 & Mangifera indica & 5.37 \\
46 & Calophyllum calaba & 5.35 \\
47 & Gomphia serrata & 4.75 \\
48 & Diospyros ebenoides & 2.78 \\
49 & Glochidion nemorale & 2.78 \\
50 & Pterospermum suberifolium & 2.78 \\
51 & Crptocarya wightiana & 2.72 \\
52 & Gomphandra coriacea & 2.71 \\
53 & Salacia oblonga & 2.65 \\
\cline { 2 - 2 } & Total carbon & \\
\cline { 2 - 2 } & & $\mathrm{kg} / 2,000 \mathrm{~m}$ \\
\hline
\end{tabular}



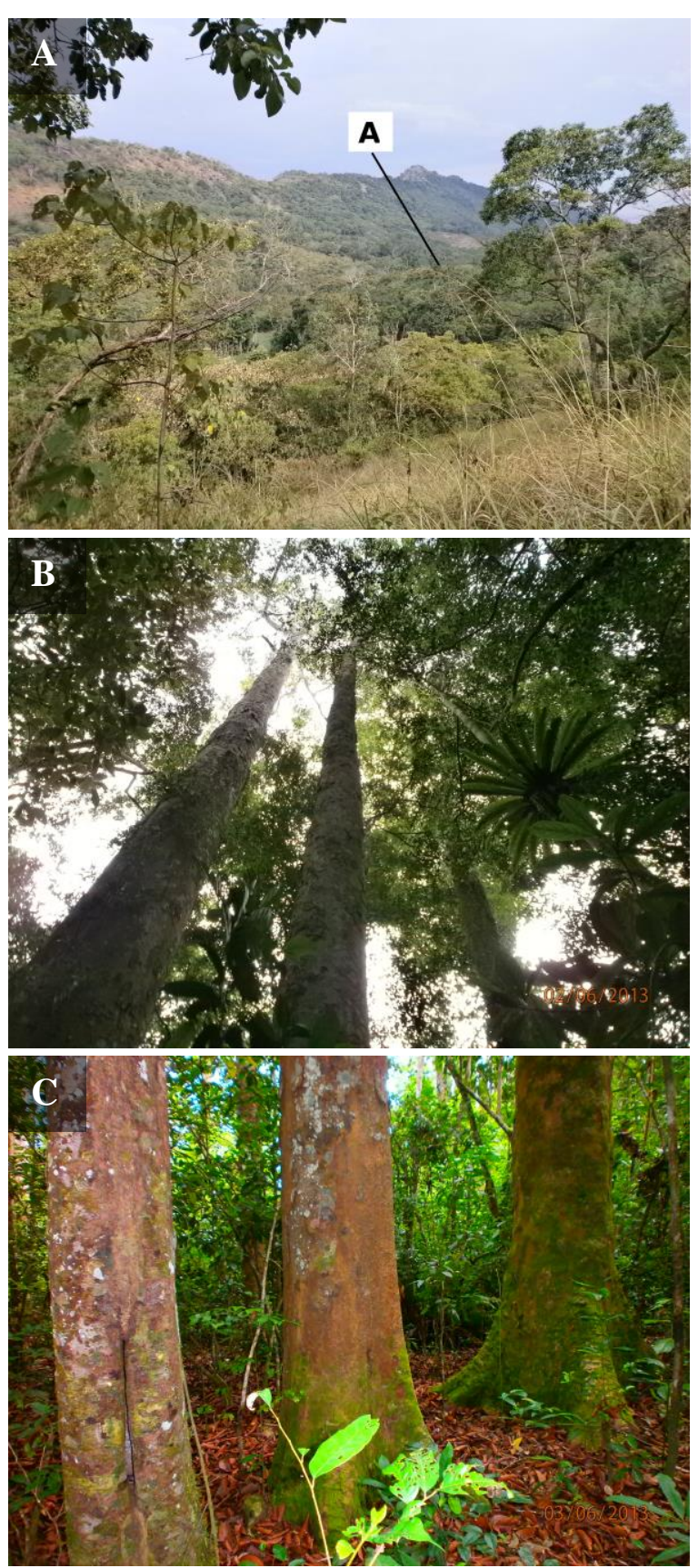

Figure 1. (A) The study site in relation to larger landscape view; (B) Lofty dipterocarp trees in the forest; and (C) Frequent occurrence of large trees close to each other largely contributes to high level of carbon stock in the forest.

The dipterocarp-dominated forest stand at Udakeeruwa can be classified as the tallest canopy natural forest in Sri Lanka. Dipterocarptree species are the prominent component of the uppermost layer of the forest canopy. This forest stand has the potential for attracting eco-tourists, researchers and other interest groups on account of its outstanding botanical features and charisma. Meanwhile, due attention has to be paid to strengthening its conservation in a socially beneficial manner, considering the ongoing anthropogenic pressures on the forest. It seems likely that taller trees, than those noted here, are to be found in this forest. The use of advanced techniques like laser scanning (Dockril 2016) for the accurate non-destructive measurement of tree heights might be used and could add valuable data to help conserve the forest.

The present initial study on forest carbon stocks of Udakeeruwa forest enriches the current knowledge base on the carbon sequestration potential of another forest in a remote locality in Sri Lanka. As per available literature, the forest carbon stock of this forest is the highest for a natural forest in Sri Lanka, which calls for policy and programs to protect this carbon rich natural forest for climate benefits. Information on taller tree species with higher carbon stocks provide guidance on plant selection for restoration forestry for enhancing ecosystem services in degraded sites having climatically similar conditions.

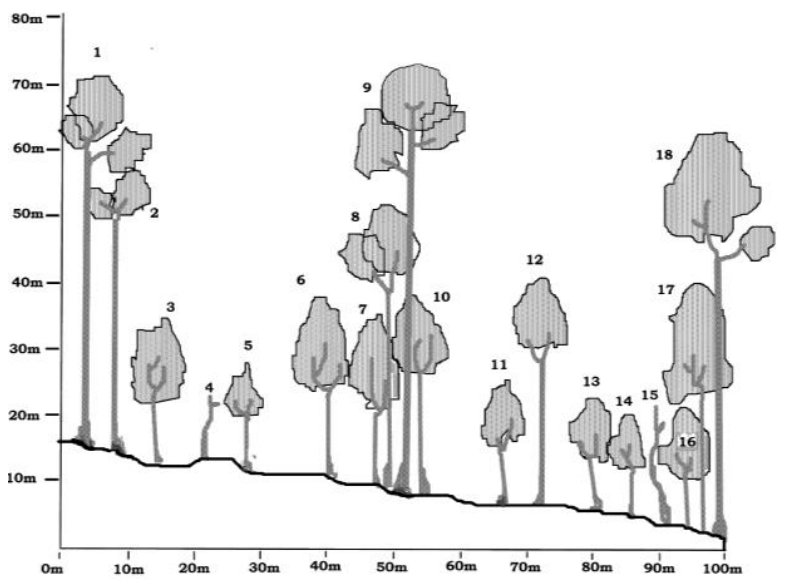

Figure 2. Profile diagram of a forest patch at Udakeeruwa; Bhesa ceylanica (7), Dipterocarpus zeylanicus $(2,8,12,18)$, Mallotus fuscescens $(3,5,6$, 10, 11, 14, 16), Pometia pinnata (13, 17), Shorea dyeri $(1,9)$ and dead stumps of large trees $(4,15)$; transect size: $100 \mathrm{~m} \times 5 \mathrm{~m}$; minimum $\mathrm{GBH}$ of selected trees: $50 \mathrm{~cm}$.

\section{Acknowledgment}

We thank Biodiversity Secretariat (the Ministry of Environment and Mahaweli Development of Sri Lanka) for providing financial assistance for this study. Also, we appreciate the support provided by the staff of Forest Department and National Herbarium of Sri Lanka. Finally we thank Chris Margules (James Cook University, Australia) for reviewing the manuscript. 


\section{Literature cited}

Ashton, M.S., S. Gunatilleke, N. de Zoysa, M.D. Dassanayake, N. Gunatilleke and S. Wijesundera (1997). A Field Guide to the Common Trees and Shrubs of Sri Lanka. WHT Publications (Pvt.) Ltd., Sri Lanka: 432pp.

Brack, C.L. and G.B. Wood (1998). Forest Mensuration: measuring trees, stands and forests for effective forest management. Australian National University, Australia at $<$ http://fennerschool-associated.anu.edu.au/me nsuration/BrackandWood1998/MENSHOME. HTM> (Accessed on 25 November 2016).

Brown, S. (1997). Estimating biomass and biomass change of tropical forests. A primer food and agriculture organization of the United Nations, Rome, Italy. FAO Forestry Paper: 134.

Brown, S. and L.R. Iverson (1992). Biomass estimates for tropical forests. World Resources Review, 4: 366-384.

Chave, J., R. Condit, H.C. Muller-Landau, S.C. Thomas, P.S. Ashton et al. (2008). Assessing evidence for a pervasive alteration in tropical tree communities. PLoS Biology 6 (3): e45.

Dockril, P. (2016). Scientists have discovered the tallest tropical tree in the world, Science Alert, 15 Nov. $2016<\mathrm{http}: / /$ www.sciencealert.com/ scientists-have-discovered-the-tallest-tropicaltree-in-the-world> Accessed on 25 November 2016.
Gunatilleke, N., R. Pethiyagoda, and S. Gunatilleke (2008). Biodiversity of Sri Lanka. Journal of the National Science Foundation of Sri Lanka. 36: 25-62.

Koelmeyer, K.O. (1957). Climatic classification and distribution of vegetation in Ceylon. The Ceylon Forester, 3: 144-163.

Martin, A.R. and S.C. Thomas (2011). A reassessment of carbon content in tropical trees. PLoS ONE, 6 (8): e23533.

Peeris, C.V.S. (1975). The ecology of the endemic tree species of Sri Lanka in relation to their conservation. Ph.D. Thesis, University of Aberdeen, UK.

Survey Department (1988). National Atlas of Sri Lanka, Survey Department, Colombo.

Submitted: 05 March, Accepted: 31 October 2020 Section Editor: Gbadamassi G.O. Dossa

S. P. Ekanayake ${ }^{1,2} \&$ R.H.S.S. Fernando ${ }^{1}$

${ }^{1}$ Center for Applied Biodiversity Research and Education (CABRE), 209/3, Allen Avenue, Dehiwala, Sri Lanka

${ }^{2}$ E-mail:sekanayake@gmail.com

Published date: 28 November 2020 